Kastamonu Eğitim Dergisi
$\begin{aligned} & \text { Kastamonu Education Journal } \\ & \text { Mart 2020 Cilt:28 Sayı:2 }\end{aligned}$
kefdergi.kastamonu.edu.tr

\title{
Okulöncesi Eğitim Programını Değerlendirme Ölçeği’nin Geliştirilmesi'
}

\author{
Developing a Scale to Evaluate Preschool Curriculum
}

\author{
Naim ÜNVER ${ }^{2}$
}

\section{Öz}

Bu çalışma, MEB Okul Öncesi Eğitim Programını değerlendirme ölçeği hazırlamak amacıyla yapılmışır. Ölçeği geliştirmek için öncelikle okulöncesi alanında yaygın olarak kullanılan, çoklu zekâ, gelişimsel etkileşim, duyuşsal biliş, bilişsel gelişimcilik, davranış̧ılık ve Waldorf yaklaşımları incelenmiş ve madde havuzunda her bir yaklaşımdan 18 soruya yer verilmiştir. 108 sorudan oluşan aracın bu ilk hali, kapsam geçerliği çalışması için alanda 15 uzmanın görüşlerine sunulmuştur. Uzmanların önerileri doğrultusunda soru maddelerinde düzenlemeler yapılmış ve araca son şekli verilmiştir.

Küme örnekleme yöntemi esas alınarak NUTS12'ye göre belirlenen 12 bölge içinden nüfus yoğunluğu yüksek olan ve birbirine komşu olmayan 12 il seçilerek, bu illerdeki resmi okul öncesi eğitim okullarındaki toplam 324 öğretmene uygulanmıştır.

Ölçeğin güvenirlik çalışmaları için elde edilen verilere sırasıyla küresellik testi, çizgi grafiği analizi, açımlayıcı faktör analizi, güvenilirlik katsayısı hesaplama analizi, madde analizi uygulanmıştır. Ayrıca ölçme aracının güvenilir olduğunu belirlemenin bir başka yolu olan Friedman's Ki-Kare testi ve Sperman-Brown (Testi Yarılama) Testi uygulanmıştır. Bu analizler doğrultusunda ölçeğin güvenirliğinin yüksek düzeyde olduğu saptanmıştır.

AFA sonuçları doğrultusunda 5 faktör ve 67 maddeden oluşan ölçek Adana, Ankara, Bursa, Eskişehir, İstanbul, İzmir, Kastamonu ve Van illerinde resmi ve özel okulöncesi eğitim okullarında görev yapan ve lisans mezunu 978 öğretmene ulaşılmış ve uygulanmıştır. Katılımcılardan dönen formlar incelenmiş, hatalı doldurulanlar ve üç sorudan daha fazla maddeyi boş bırakanlar çıkarıldıktan sonra toplam 877 öğretmene ait verinin doğrulayııı faktör analizine (DFA) tabi tutulması kararlaştııılmışıı. Tüm DFA uygulamaları sonucunda 2/df 2,67, GFI 0,917, CFI 0,87, AGFI 0,90, RMSEA 0,04, RMR 0,06 ve SRMR 0,05 olarak bulunmuştur. Bu değerlerin, literatürde belirlenen uyum iyiliği değerleriyle uyumlu olduğu görülmektedir.

Anahtar Kelimeler: Okulöncesi eğitim programı, değerlendirme, ölçek

\section{Abstract}

This study was conducted to develop a scale to evaluate MNE Preschool Curriculum. In order to develop the scale, first of all the approaches widely used in field of preschool education, namely behaviorism, multiple intelligences, Bank Street, Montessori, High Scope and Waldorf approaches, were examined and 18 questions from each approach were included in the item pool. This first version of the tool consisting of 108 items was presented to the opinions of 15 experts in the field for the content validity. In line with the suggestions of the experts, arrangements were made in the items and the tool was finalized.

Out of 12 regions determined by NUTS12 based on cluster sampling method, 12 provinces with high population density and not adjacent to each other were selected and the scale was applied to a total of 324 teachers working at state-funded pre-school education schools in these provinces.

Sphericity test, line graph analysis, AFA, reliability coefficient calculation analysis and item analysis were applied to the data obtained for the reliability studies of the scale. Furthermore, Friedman's Chi-Square test and Sperman-Brown Test, another way to determine the reliability of the measurement tool, were conducted. According to the results of analyses, it was found that the scale is a reliable tool to evaluate pre-school curriculum.

Keywords: Preschool education program, evaluation, scale

\footnotetext{
${ }^{1}$ Bu araştırma, Gazi Üniversitesi EBE “Okulöncesi Eğitim Programını Değerlendirme Ölçeği'nin Geliştirilmesi ve Bu Ölçeğe Bağlı Olarak Öğretmenlerin Uygulamalarını Değerlendirmeleri" başlıklı doktora tezinden üretilmiştir.

${ }^{2}$ Kastamonu Üniversitesi, Eğitim Fakültesi, Okul Öncesi Eğitimi ABD, Kastamonu, Türkiye, https://orcid.org/0000-0003-1801-5609

Atıf / Citation: Ünver, N. (2020). Okulöncesi eğitim programını değerlendirme ölçeği'nin geliştirilmesi. Kastamonu Education Journal, 28(2), 891-909. doi:10.24106/kefdergi.697826
} 


\section{Extended Abstract}

Introduction: Resently, the researches have focused on the qualities of the education to be given based on the necessities of preschool education. Besides taking pre-school education, in order to achieve the desired aim the path to be followed within the framework of this education is of great importance (Kalıpsı, 2008). In this respect, although there are many approaches in the field of preschool education, the main objective of these approaches is to develop children in the most efficient way and in all developmental areas. In our country, the philosophies and how they are used in education of such approaches as Bank Street, Montessori, High-Scope, Waldorf, Reggio Emilia and Open School are taught/introduced theoretically or in the subjects of practical courses to pre-school education teacher candidates in undergraduate education. In this research, a scale to evaluate the MoNE Preschool Education Program was developed. In the item pool, questions were formed from applications of Behaviourist (Direct Command), Developmental Interaction (Bank Street), Sensory Cognition (Montessori), Cognitive Developmentalism (High-Scope), Multiple Intelligence and Waldorf approaches. Although Bank Street, Montessori, High-Scope and Waldorf approaches are direct approaches to preschool education, behaviourism and multiple intelligence approaches are also seen as pre-school education approaches.

Methods and Findings: In order to develop the scale, firstly the approaches of multiple intelligence, developmental interaction, affective cognition, cognitive developmentalism, behaviourism and Waldorf approaches which are widely used in preschool field have been examined and a pool of 108 items has been formed which includes the remarks of these approaches of the program. While preparing the question items, the "Early Childhood Curriculum Belief Scale" developed by Jensen (2004) and the "Turkish adaptation: The Reliability and Validity Study" of the Scale "Views of Early Childhood Approaches" conducted by Soydan (2013) were used. The item pool contains 18 questions from each approach. This initial version of the 108-item tool was presented to the opinions of 15 experts (Child Development, Preschool Education, Assessment and Evaluation, Educational Management and Psychological Counselling and Guidance) for the content validity study. Thus, the question of to what extent the substances in the tool are sufficient to cover and collect the required factual and / or judicial data was sought.

A questionnaire of 108 items, whose validity studies were completed through literature review and expert opinion, was used as a five-point Likert for teachers to answer the questions. Five Likert items are $1=$ disagree, $2=$ partially agree, $3=$ disagree, $4=$ generally agree, 5 = completely agree. The first version of the scale was applied to 400 preschool teachers working in state schools in these provinces by selecting 12 non-neighbour provinces with high population density among 12 regions determined according to NUTS12 based on cluster sampling method. The returned questionnaires were examined and it was decided to analyse the data of a total of 324 teachers' data after the incorrectly filled out questions and those who left more than five items blank.

Sphericity test (KMO) was used to determine the suitability of the collected data for exploratory factor analysis (EFA). As a result of KMO Bartlett's test, KMO value was found to be 0.898 and Bartlett's Chi Square value was found as 21209.117 ( $p$ : 0.000 ). These values indicate that exploratory factor analysis (EFA) can be conducted on 108 item pool. The data were subjected to AFA analysis 5 times and at the end of the fifth application, it was found that there were no items with a common variance value below .30. As a result of the fifth and last AFA, the scale consisted of 5 factors and 67 items. The percentage of explanation of the total variance of factor 1 before rotation was 18,223, the percentage of explanation of total variance of factor 2 was 5,803, the percentage of explanation of total variance of factor 3 was 2,784, the percentage of explanation of total variance of factor 4 was 2,218 , the percentage of explanation of total variance of factor 5 was 1,939. After rotation, total variance explanation percentage of factor 1 was calculated as 14,328, total variance explanation factor of factor 2 was 13,949, total variance explanation factor of factor 3 was 6,995, total variance explanation factor of factor 4 was 6,022, and total variance explanation factor of factor 5 was calculated as 4,927. As a result of the applied factor analysis, it was seen that Cronbach-Alpha coefficient of the remaining 67 items was 0.946. Friedman's chi-square test found that Friedman's chi-square $=7638,500(p=0,000)$. The reliability of the tool was calculated by using the Sperman Brown test half-way method and the Cronbach's Alpha coefficient of the first half of the test was 0.906 , and the second half of the test was found to be 0.900 and the correlation coefficient between the two questionnaires (split) was 0.832 . These findings indicate that the scale is highly reliable. However, since the scale consists of 5 factors, a reliability analysis was performed for each factor in order to better understand the relationships between multiple variables. Prior to this stage, the factors were named after consultation with 10 pre-schoolers and 3 assessment experts. According to this, the first factor is named as "Teachers' Opinions about Teacher Roles", the second factor "Teachers' Opinions about the Program and Evaluating Children ", the third factor Teachers' Opinions about Organizing Small Group Activities and Evaluating Children in Activities Etkinlik, Factor 4 "Teachers 'Opinions about Planning Activities "and Factor 5" Teachers' Opinions about Reflecting and Evaluating Daily Living Activities to the Program". Afterwards, reliability analysis was performed for each factor separately. The teachers' opinions about teacher roles were composed of 19 items and had 49,71 arithmetic mean, 12,408 standard deviation and 153,949 variance, and Cronbach's Alpha reliability coefficient was found to be 0.926. Teachers' opinions about the program and assessment of children consist of 24 items, 96.82 arithmetic mean, 14.849 standard deviation and 220.487 variance, and Cronbach's Alpha reliability coefficient is 0.929. Teachers' opinions about arranging small group activities and evaluating children in the activities factor has 10 items and has 35,08 arithmetic mean, 6,920 standard deviation and 47,886 variance. The Cronbach Alfas Alpha reliability coefficient was 0.814 . Teachers' opinions about planning activities are composed of 8 items, 19,25 arithmetic mean, 6,103 standard deviation and 37,250 variance. The Cronbach's Alpha reliability coefficient is 0.764 . Teachers' opinions about reflecting and evaluating daily life activities into the program factor has 6 items and has 17,91 arithmetic mean, 5,134 standard deviation and 26,362 variance. Cronbach's alpha reliability coefficient was calculated as 0.762 . 
According to the exploratory factor analysis results, the scale consisting of 5 factors and 67 items was applied to 978 teachers who worked in public and private preschool education schools and who have a bachelor's degree in Adana, Ankara, Bursa, Eskişehir, istanbul, izmir, Kastamonu and Van. After the questionnaires are returned by the participants, the ones filled out incorrectly and the ones who left more than three questions blank were removed, it was decided that a total of 877 teachers' data would be subjected to confirmatory factor analysis (CFA). As a result of all DFA applications, 22 / df 2.67, GFI 0.917, CFI 0.87, AGFI 0.90, RMSEA 0.04, RMR 0.06 and SRMR were found to be 0.05. These values are consistent with the goodness of fit values determined in the literature.

Results and Discussion: Within the scope of the validity studies of the scale, literature review and expert opinion were taken and studies were conducted and item pool was formed in line with expert opinions. Respectively, the sphericity test was conducted to determine the suitability of the data for exploratory factor analysis, , the line graph analysis was cond ucted to determine how many factors the scale consists of, the explanatory factor analysis was conducted to determine the variance disclosure values of the scale items, reliability coefficient calculation analysis was used to determine the consistency of the items in the measurement tool and to be able to determine how stable it is to measure the properties it wants to measure, and item analysis was used to calculate the correlation coefficient of each item in the scale. In addition, another way to determine the reliability of the measurement tool Friedman "s Chi-Square test and Sperman-Brown Test was conducted.

As a result of the KMO Bartlett test, KMO value was found to be 0.898 and Bartlett Chi Square value was found as 21209.117 (p: 0.000).

As a result of the EFA, the data collection tool was found to have 5 factors on the line graph. The total variance explanation percentage of the first factor in the scale was calculated as 14,328, the total variance explanation factor of the 2nd factor was 13,949 , the total variance explanation factor of the 3rd factor was 6,995, the total variance explanation factor of the 4th factor was 6,022, and the total variance explanation factor of the 5th factor was calculated as 4,927.

As a result of factor analysis, Cronbach-Alpha coefficient of the remaining 67 items in the scale was found to be 0.946.

Friedman's chi-square test found that Friedman's chi-square $=7638,500(p=0,000)$.

The reliability of the tool was calculated by using the Sperman Brown test half-way method and the Cronbach's Alpha coefficient of the first half of the test was 0.906 , and the second half of the test was found to be 0.900 and the correlation coefficient between the two questionnaires (split) was 0.832 .

According to the exploratory factor analysis results, when the scale consisting of 67 items and five factors the scale was applied to the CFA four times and 34 items were removed from the scale and the number of factors remained the same. When the goodness of fit values of CFA is examined, it is seen that the values are acceptable. After all these studies, "Preschool Curriculum Evaluation Scale" consisting of 33 items and 5 factors was introduced to the literature and practitioners. 


\section{Giriş}

Toplumların sosyal, kültürel, siyasi ve iktisadi yönden kalkınmasında ve bireylerin kendilerini gerçekleştirmesinde önemli bir role sahip olan eğitim sistemi üç temel öğeden oluşur. Bu öğeler; öğrenci, öğretim hizmeti ve eğitim programlarıdır. Eğitim programları o ülkedeki eğitimin niteliği ile doğrudan ilişkilidir. Ayrıca eğitim sisteminde ortaya çıkacak problemlerin çözümü, bu ülkede izlenen milli eğitim politikalarına ve eğitim programlarının geliştirilmesine bağlıdır. Eğitim sisteminde yapılan düzenlemeler, eğitim programlarında yer aldığı ölçüde anlam kazanır. Programlar ulaşılmak istenen amaçları/hedefleri, bu hedeflere ulaşmak için belli ilkelere göre düzenlenmiş içeriği, hedeflere ulaşmak için kullanılacak yöntemleri, teknikleri, araç-gereçleri ve hedeflere ulaşma düzeyini belirleyecek değerlendirme çalışmalarını kapsar.

Eğitim programları farklı öğelerden oluşsa da bütün halindeki bir düzenek olarak kabul edilir, sistematik ve dinamik bir yapı olarak görülür. Programın temel öğelerinden (hedef-içerik-eğitim durumları-değerlendirme) biri değiştiğinde diğer öğeler de bu değişimden etkilenir. Eğitim programına dinamizm katan öğe ise değerlendirme öğesidir. Zira programlar nitelikli şekilde değerlendirildiği takdirde eksikler görülüp, düzeltilebilir ve program geliştirilebilir. Eğitim programları; bireylere kazandırılacak davranışları, öğretilecek bilgi ve becerileri önceden belirler. Bireylerin istenilen özellikleri kazanıp, kazanmadığının saptanması ise, eğitim programının etkililiği hakkında bilgi verir. Eğitim programlarının belirlenmesi, uygulanabilmesi ve bireylerde istendik yönde davranış değişikliklerine yol açabilmesi için her fırsatta gözden geçirilerek değerlendirilmesi gerekir. Yapılan bu değerlendirmeler, eğitim programlarının niteliğini artııı. Nitelikli eğitim programları ise nitelikli eğitim anlamına gelir. (Akınoğlu, 2005; Bilasa, 2006; Demirel, 2003;Sönmez, 1998; Tertemiz, 1997; Varış, 1994).

Nitelikli bir okul öncesi eğitim programı; programın uygulandığı okullarda öğretmen ve çocuk arasındaki iletişim sayesinde çocuğun benliği hakkında olumlu düşünce geliştirmeli, çocuğa saygı duymalı ve olumlu destek sağlamalıdır. Çocuğu öğrenme sürecine aktif şekilde katılması konusunda cesaretlendirmelidir. Çocuğun gelişen dünyaya uyum sağlamasına yarımcı olmalı, onlara kültürel değerler aşılamalı ve farklı kültürlere duyarlı olmayı öğretmelidir. Ayrıca çocukların kendi yeteneklerinin farkına varmasını ve dili etkin şekilde kullanmasını sağlamalıdır (Gordon \& Browne, 2014; Tuncer, 2015).

Ülkemizde 2013 yılında yürürlüğe giren "36-72 Aylık Çocuklar için Okul Öncesi Eğitimi Programı”, ulusal ve uluslararası alan araştırmaları, uygulamadan gelen geri bildirimler ve "Okul Öncesi Eğitiminin Güçlendirilmesi Projesi" çalışmaları kapsamında yapılan mevcut durum analizleri dikkate alınarak hazırlanmış, denenip geliştirilmek üzere uygulamaya konulmuş ve bu süreçte okul öncesi eğitimi veren bütün paydaş kurum ve kuruluşların da katkıları dikkate alınarak program geliştirme çalışmaları tamamlanmıştır. Bu program, çocukların gelişimsel özelliklerini, ilgi ve gereksinimleri ile çevresel koşullarını dikkate alan gelişimsel, sarmal ve eklektik bir yapıdadır. Okul öncesi eğitim kurumlarına devam eden çocukların zengin öğrenme deneyimleri aracılığıyla sağlıklı büyümelerini, bütün gelişim alanlarının desteklenerek en üst düzeye ulaşmasını, öz bakım becerilerini kazanmalarını ve temel eğitime hazır bulunmalarını sağlamak amacı ile geliştirilmiştir (MEB, 2013).

Günümüzde yapılan araştırmalar, okul öncesi eğitimin gerekliliğinden yola çıkarak verilecek eğitimin niteliklerine yoğunlaşmıştır. İstenilen amaca ulaşabilmek için okul öncesi eğitim alınmasının yanı sıra bu eğitimin çerçevesinde izlenecek yolun önemi büyüktür (Kalıpçı, 2008). Bu doğrultuda okul öncesi eğitim alanında birçok yaklaşım olsa da bu yaklaşımların temel hedefi, çocukların en verimli şekilde ve tüm gelişim alanlarında desteklenmesidir. Ülkemizde lisans eğitiminde okul öncesi öğretmen adaylarına Bank Street, Montessori, High-Scope, Waldorf, Reggio Emilia ve Açık Okul gibi yaklaşımların felsefeleri ve eğitimde nasıl kullanıldıkları teorik ya da uygulamalı derslerin konuları içerisinde öğretilmekte/tanıtılmaktadır. Bu araştırma MEB Okul Öncesi Eğitim Programını değerlendirecek bir ölçek geliştirmek amacıyla yapılmıştır. Ölçekte Davranışçı (Direkt Komut), Gelişimsel Etkileşim (Bank Street), Duyusal Biliş (Montessori), Bilişsel Gelişimcilik (High-Scope), Çoklu Zekâ ve Waldorf yaklaşımlarına ait uygulamalardan oluşturulmuş sorular kullanılmıştır. Bank Street, Montessori, High-Scope ve Waldorf yaklaşımları doğrudan okul öncesi eğitime yönelik yaklaşımlar olmakla birlikte davranış̧̧ıık ve çoklu zekâ yaklaşımları uygulamalar da okul öncesi eğitimde yer bulan yaklaşımlar olarak görülmektedir.

\section{Davranış̧ı (Direkt Komut) Yaklaşım}

Eğitim sistemlerinde pek çoğunu sorgulamadan kabul edilen birçok genel-geçer uygulamalar davranış̧̧ı yaklaşımın bir sonucudur. Davranış̧̧ı ekol, nesnellik, aşamalııı, tekrar ve pekiştireç odaklıdır. Öğretmen otorite rolündedir, tüm aktiviteleri planlar ve yürütür. Bilgi dış kaynaklıdır ve öğretmen tarafından öğrencilere aktarılır. Öğrenciler duydukları ve okudukları şeyleri öğrenirler. Öğretmen soyut kavramları etkili şekilde açıklarsa, öğrenciler bu kavramları 
öğrenebilir. Ve öğrendiklerini tekrar ederlerse başarılı olurlar. Ödül ve övgü çocukların motive olmasını sağlar. Olumlu pekiştireçler kalıcı öğrenmeler açısından önemlidir. Olumlu pekiştireç; ortama konulduğunda belirli bir davranışın yapılma olasılı̆ı̆ı artıran uyarıcılardır (Arslan, 2007; Özden \&Şimşek, 1998; Senemoğlu, 2005). Kitap ve çalışma yaprağı gibi kaynaklar sınıf içi aktivitelerin temelini oluşturur. Materyalle öğretime önem verilmektedir. Kullanılan materyaller aşamalııık özelliğine göre düzenlenmiştir. Davranışın ölçülebilir ve gözlenebilir olması için öğrencinin etkinliklere katılması gerekir. Davranışçı ekolde ceza da kullanılır. Ceza herhangi bir davranışın olma şansını azaltan ardışık eylemlerdir. Fakat ceza davranışta kısa süreli değişiklik oluşturabilir. Cezanın etkisi geçtiğinde çocuk olumsuz davranışı sürdürebilmektedir. Davranış̧̧ılıkta doğru/istendik davranışlar pekiştirilir. Bu pekiştireçler sayesinde olumlu davranışların yapılma sıklığı artar. Kriter-referans testleri, çalışma yaprakları ve sözlü cevaplar çocuk hakkında yapılacak dönüt-düzeltme işlemi için bilgi temin etmede yeterlidir (Jensen, 2004; Özbay, 2004; Şafak, 2011).

\section{Bank Street (Gelişimsel Etkileşim) Yaklaşımı}

Bank Street yaklaşıma göre eğitimin amacı, sadece zekâya dayanmamalı, çocuğun sosyal, duygusal ve fiziksel gelişimi de göz önünde bulundurulmalıdır. Erken çocukluk eğitimi dil ve yazma, matematik, dramatik oyun, sanat müzik hareket, bilim ve sosyal bilimler olarak ayrılmıştır. Çocuklar sınıfta araştırma ve deney yapmaya meraklıdırlar. Öğrenim gezileri programın önemli bölümlerindendir. Bu alan gezileri ile çocuklar; kendi yeteneklerini tam kapasite kullanma fırsatı elde eder. Öğretmenlerin öncelikli görevi çocukları gözlemlemek, öğrenmelerine rehberlik etmek amacıyla oyuna dayalı deneyim planı hazırlamaktır. Bu sayede günlük etkinliklere şekil veren öğretmen, çocukların öğrenme düzeyini artırmaya çalışır. Öğretmen bu yaklaşımda program geliştirici olarak görülür. Bank Street yaklaşımında sınıflarda birden fazla öğretmen bulunabilir. Değerlendirme standart amaçlar yerine öğretmenin gözlemleri ve çocukların çalışmalarından oluşan portfolyoya dayanır. Okul-aile-öğretmen işbirliği programda önemli bir yer teşkil eder. Ayda bir kez ailelerden biri okula kahvaltıya davet edilerek, çocuklarla birlikte hikâye okuma, müzik, sanat vb. etkinliklere katılırlar (Anonim, 2019; Bayhan \& Bencik, 2008; Jensen, 2004).

\section{Montessori (Duyuşsal Biliş) Yaklaşımı}

Montessori yaklaşımı kendi dönemi içerisinde "çocuktan hareket" akımının temsilcisi olarak tanımlanmaktadır. Montessori, çocuğu sadece eğitimin bir öznesi olarak değil, çocuğu gelişimsel olarak da incelemiştir. Gelişimsel bir pedogoji olan Montessori yaklaşımı çocuğu merkeze alan felsefesi ile birliktenbir eğitim ortamı geliştirmiş ve çocukların sahip oldukları potansiyeli açığa çıkarmak için uygun ortamların hazırlanması gerektiğini vurgulanmıştır. Özel tasarlanmış araçlar programın merkezini oluşturur. Montessori çocuğun tüm gelişim aşamalarının ihtiyaçlarını karşılamak için bir yöntem ve bu yöntemin işlemesi için materyaller geliştirmiştir. Montessori yönteminde çocuğun öğrenme arzusunu ve kendi yeteneklerini geliştirme potansiyelini desteklemek için bütünüyle hazırlanmış çevreden faydalanır ve çocuğa bu önceden hazırlanmış ve yapılandırılmış bir çevrede özgürlük tanınır.

Montessori'ye göre çocuklar en iyi öğrenmeyi zengin uyarıcılarla dolu ve özgür hissettikleri öğrenme ortamlarında yaparak ve keşfederek gerçekleştirebilirler. Bu özgür ortam çocukların aynı zamanda öz disiplin kazanmalarını da destekler (Kartal, 2008; Lynn \& Obain, 1996; Montessori, 1997; Toran \& Temel, 2014). Hazırlanan bu uygun ortamlarda çocuklara kendilerini ifade etme ve gelişmelerini özgürce gerçekleştirme fırsatı verilmesinin önemi üzerinde durur (Oktay, 2004). Montessori sınıfında eğitici materyaller kullanılarak çocuğa oto-eğitim yapma fırsatı, bireysel çalışma özgürlüğü, zihinsel gelişim ihtiyaçlarını karşılama, sosyal çevreye uyum ihtiyacını karşılama ve kendi kendine yetebilme becerileri kazandırılır (Daoust, 2004; Williams, 1996). Montessori eğitimcisi sınıf içerisinde bulunan materyalin nasıl kullanıldığını, hangi materyalin hangi yaştaki çocuğa sunulması ve materyalin ne zaman geri çekilmesi gerektiğini bilir (Toran, 2011). Montessori eğitimcisinin önemli görevlerinden bir diğeri ise iyi bir gözlemci olmasıdır. Öğretmen çocuğun gelişiminin gözlemcisidir ve materyal kullanımına rehberlik eden bir kaynak olarak görev yapar (Jensen, 2004; Temel, 1994).

\section{High Scope (Bilişsel Gelişimcilik) Yaklaşımı}

High Scope yaklaşımında etkin öğrenme programın merkezinde yer alır ve temel deneyimler planla-yapdeğerlendir etkinlik döngüsünde hazırlanır. Etkin öğrenmenin gerçekleşmesi için her şeyden önce öğrenenin önünde çeşitli materyaller bulunmalıdır (Yıldız, 2000). Çocuklar için en iyi öğrenmenin çocukların kendi planladıkları, uyguladıkları ve değerlendirdikleri etkinlikler yoluyla gerçekleşeceği savunulmuştur. Öğretmen bu süreci gözlemleyen, destekleyen ve rehber konumunda olan kişidir. Öğretmen çocuğun yeteneklerini geliştirebilmesi adına çocuk ve çevresi arasında değişim yaratmalıdır. Okul öncesi eğitim programlarının nitelikli olması için önemli ölçütler arasında gösterilen öğretmenlerin yeterlik düzeyi, ailelerle işbirliği, yönetimsel ve idari destek gibi boyutlar High Scope programında vurgulanır (Schweinhart, 2002). Yaklaşımın kurucu olan Wiekart’a (1971) göre öğretmene kuramla uygulamayı nasıl buluşturacağını açık bir şekilde gösteren programların, başarılı olmaktadır. Bununla birlikte Wiekart programın 
personelde planlama ve değerlendirme becerilerini geliştirmeye yönelik etkili bir eğitim modeli içermesi gerektiğini savunmuştur (Weikart, 1971). Zihinsel gelişim çocuğun gelişiminde en önemli öğedir. Bir insanın hayatının hemen hemen tüm yönü düşünceden ve dilden etkilenmiştir. Çocuklar bilgiyi insanlarla, nesnelerle ve fikirlerle aktif ilişki aracılığı ile edinirler. Öğretmenin rolü çocuğun ilgi alanlarını takip etmektir, çünkü programın temeli buna dayanmaktadır. Öğretmen çocukların aktivitelerine uygun biçimde katılmaktadır. Planlama, öğretmenin öğrencilerin neye ilgi duyduklarını belirlemesi ve onların ilgilerine göre yapılması amacıyla günlük olarak hazırlanır. Çocuklar için aynı günün aynı saatinde aynı aktivitelerin yapılması gibi sürekli rutin aktiviteler gerekli görülür (Jensen, 2004).

\section{Waldorf Yaklaşımı}

Waldorf yaklaşımı, çocuk ruhunun düşünme, hissetme ve istekli olma yapısının gelişmesini sağlayarak, yaşam hakkında bilgi sahibi olma ve sağlıklı ve yapıcı bir yolla yaşamda aktif rol almasına yardımcı olabilme amacını güder. Waldorf yaklaşımında temel ilke öğrencilerin kendi görgülerini ve dünyadaki yerlerini anlamaya yönelik bir anlayış biçimi geliştirmektir. Çağdaş bir içeriği çocuğa zorla öğretmek yerine, çocuğun uyarılmış ve geliştirilmiş yeteneklere ulaşmasını amaçlar (Bayhan \& Bencik, 2008). Bilim ve sanatı bir bütünün parçaları olarak gören Waldorf eğitim yaklaşımında eğitimin "sanat" olduğu görüşü hakim olup zihinsel gelişimle birlikte duygusal ve ahlaki gelişim de ön planda olmalıdır. Çocuğu eğitmek için; akla olduğu kadar; kalbe ve arzulara da önem verilir. Akademik başarının yanında kişisel başarının da artıııması amaçlanır. Waldorf eğitim yaklaşımı geleneksel ezberci yöntemleri reddederek çocuğun yaratıcı düşünce ve hayal gücünü destekleyen sanat ve bilim ile birlikte öğrenmeyi amaçlar (Şener, 2001). Waldorf sınıflarında elektronik ve plastik materyaller yer almaz (Toran, 2014). Waldorf eğitimcileri, sürekli gelişimi meslekî niteliğin en önemli boyutu olarak görmektedirler. Çünkü bir ilkokulda ana ders öğretmeni bir sınıfı birinci sınıftan sekizinci sınıfa kadar okutur (Kalıpçı, 2008). Waldorf yaklaşımında, okulun eğitim felsefesi olarak en temel kaygılarından biri, herkese belli düzeyde bir estetik kabiliyet kazandırmaktır. Onun için düşünceler, hayaller, imajlar elden geldiğince serbest bırakılmaktadır (Kaya\&Gündüz, 2015). İngiltere'deki Waldorf okulları üzerinde yapılan araştırmanın sonucunda bu okulların sekiz temel özelliğine değinilmiştir. Bu özelliklere bakıldığında Waldorf okullarının çocukların ihtiyaçlarına yönelik bütüncül bir eğitim verdiği ortaya çıkmaktadır.

1. Bütünden parçaya doğru bir program anlayışı

2. Çocuk gelişimine verilen önem

3. Özgürlük hedefi

4. Öğretmen ve öğrenciler arasındaki yakın ilişki

5. Sözel gelenekler

6. Rutinler ve ritüeller

7. Sanat ve yaratıcılık

8. Goethe temelli bir bilim anlayışı (Woods, Ashley ve Woods, 2005).

\section{Çoklu Zekâ Yaklaşımı}

Çoklu Zekâ Kuramı, eğitimcilerin öğrenmeyi etkileyen çevresel faktörleri gözlemleyebilecekleri bir kalıp sunarak sınıf içi aktivitelerin düzenlenmesinde öğretmenlere yardımcı olur. Öğrenmeyen öğrenci, başarısız öğrenci fikrini kabul etmeyen bu kurama göre, öğrenme faaliyetlerinin öğrencinin zekâ türlerine yönelik olarak düzenlenmesi gerekliliğine dikkat çeker (Armstrong, 2009; Azar, Presley \& Balkaya, 2006). Bu teori öğrencilerin daha iyi öğrenmelerini sağlamada, yeni yaklaşımların oluşturulmasında, güçlü zekâ alanlarının ortaya çıkarılmasında ve öğretmenlerin, öğrencilerin öğrenmelerini değerlendirilmesinde önemli katkılar sağlar (Goodnough, 2001). Okulöncesi eğitim programları, çocuklara ileriki yaşamlarında onları yönlendirecek fırsatları sunar. Çocuklara rehber olması amacıyla çizilen yolların doğru ve çok seçenekli olması önemlidir. Çocukların sahip oldukları zekâ alanlarının farkına varmalarını sağlamak ve her zekâ alanının özelliklerine uygun gelişme şansının tanınması okulöncesi eğitim programları kapsamında olmalıdır (Tuğrul \& Duran, 2003).

Okullar çocukların özgüven ve başarılı olma tutumlarının gelişimine yardım etmeye çalışır. Gardner"ın teorisi değişik yeteneklere sahip çocukların tanınmasına kaynaklık eder. Bir çocuk matematiksel veya sözel alanda yetenekli değilken, diğer zekâ alanlarında uzmanlaşabilir. Her çocuğun ihtiyaçlarına ve özgünlüğüne uygun ortam yaratılırsa çocukların programa katıımları üst düzeyde sağlanmış olur. Eğitimciler çocukların gelişmiş oldukları zekâ alanlarını destekleyerek herhangi bir konuyu "nasıl daha kolay öğrenebileceklerini" keşfetmelerini sağlayabilirler (Brualdi, 1998). 


\section{Yöntem ve Bulgular}

\section{Veri toplama aracının geliştirilmesi}

Ölçeği geliştirmek için öncelikle okulöncesi alanında yaygın olarak kullanılan, çoklu zekâ, gelişimsel etkileşim, duyuşsal biliş, bilişsel gelişimcilik, davranış̧ııı ve Waldorf yaklaşımları incelenmiş ve bu yaklaşımların programa ilişkin görüşlerini kapsayan 108 sorudan oluşan bir madde havuzu oluşturulmuştur. Soru maddeleri oluşturulurken, Jensen (2004) tarafından geliştirilen "Erken Çocukluk Müfredat İnancı Ölçeği” ve bu ölçeğin Soydan (2013) tarafından yapılan "Erken Çocukluk Yaklaşımlarına iliş̧in Görüşler Ölçeği "nin Türkçe Uyarlaması: Geçerlik ve Güvenirlik Çalışması"ndan faydalanılmıştır. Bu madde havuzunda her bir yaklaşımdan 18 soruya yer verilmiştir. 108 sorudan oluşan aracın bu ilk hali, kapsam geçerliği çalışması için alanda 15 uzmanın (Çocuk Gelişimi, Okul Öncesi Eğitimi, Ölçme ve Değerlendirme, Eğitim Yönetimi ve Psikolojik Danışma ve Rehberlik uzmanlık alanlarından) görüşlerine sunulmuştur. Böylelikle araçtaki maddelerin, ihtiyaç duyulan olgusal ve/veya yargısal verileri kapsamada ve toplamada ne derece yeterli olduğu sorusunun cevabı aranmıştır (Büyüköztürk, 2005). Uzmanların önerileri doğrultusunda soru maddelerinde dil ve üslup birliğinin sağlanması ve çok uzun olan soruların kısaltılması düzenlemeleri yapılmış ve araca son şekli verilmiştir. Soru sayısı ise değişmemiştir.

\section{Verilerin toplanması}

Bölgesel gelişme alanında Avrupa Birliği'ne uyum sürecinin bir gereği olarak, yerleşme merkezlerinin kademelenmesini, iller arasındaki fonksiyonel ilişkileri, coğrafi koşulları, istatistik toplama ve plan yapma amacına uygunluğu da dikkate alarak Türkiye'de de üç kademeli İstatistiki Bölge Birimleri Sınıflandırması (IBBS) yapılmıştır (Taş, 2006). Ülkemizde geleneksel olarak kullanılan yedi coğrafi bölgeye ek olarak, 22 Eylül 2002 tarihinde yeni bir bölge sınıflandırılması oluşturulmuştur. Böylece bölge sayısı 12"ye çıkarılmıştır. (NUTS12 :The Nomenclature of Territorial Units for Statistics - İstatistiki Bölge Birimleri Sınıflandırması). Bu yeni düzenleme Türkiye'nin Avrupa Birliğine uyum süreci doğrultusunda çıkartılan 2002/4720 sayılı kanuna dayanmaktadır.

Literatür incelemesi ve uzman görüşü yoluyla geçerlik çalışmaları tamamlanan ölçekteki 108 soru maddesi öğretmenlerin soruları yanıtlaması için beşli likert kullanılmıştır. Beşli likert öğeleri 1=hiç katılmıyorum, 2=kısmen katılıyorum, 3=katılmıyorum, 4=genellikle katılıyorum, 5=tamamen katılıyorum şeklindedir (Büyüköztürk, Akgün, Karadeniz, Demirel \& Kılıç, 2008). Ölçeğin ilk hali küme örnekleme yöntemi esas alınarak NUTS12'ye göre belirlenen 12 bölge içinden nüfus yoğunluğu yüksek olan ve birbirine komşu olmayan 12 il seçilerek bu illerdeki resmi okullarda görev yapan 400 okul öncesi öğretmenine uygulanmıştır. Katılımcılardan dönen formlar incelenmiş, hatalı doldurulanlar ve beş sorudan daha fazla maddeyi boş bırakanlar çıkarıldıktan sonra toplam 324 öğretmene ait verinin incelenmesi kararlaştırılmıştır. Öğretmenlere erişimde pratik bir yol olması ve çok sayıda öğretmenlere hızlı erişim sağlanması açısından sosyal medya üzerinden uygulanması hedeflenmiştir. Bu amaçla öncelikle "Google Dokümanlar" veri tabanı üzerinde bilgi formu ve ölçeğin tanımlanması yapılmıştır. Sayfa oluşturulduktan sonra araştırmacının sosyal medya sayfasından belirlenen illerde görev yapan tamamı lisans mezunu ve Milli Eğitim Bakanlığı'na bağlı resmi okullarda çalışan öğretmenlere tek tek ulaşılmış ve iletilen linkten formu doldurmaları istenmiştir. Seçilen bölge ve illerin dağııımı Tablo 1'de görülmektedir.

Tablo 1. NUTS12 bölgeleme sistemine göre belirlenen illerin dağılımı

\begin{tabular}{ll}
\hline NUTS 12 BÖLGELER & SEÇiLEN IL \\
\hline 1. Bölge-İstanbul & İstanbul \\
2. Bölge-Batı Marmara & Çanakkale \\
3. Bölge-Ege & İzmir \\
4. Bölge-Doğu Marmara & Sakarya \\
5. Bölge-Batı Anadolu & Ankara \\
6. Bölge-Akdeniz & Mersin \\
7. Bölge-Orta Anadolu & Kayseri \\
8. Bölge-Batı Karadeniz & Kastamonu \\
9. Bölge-Doğu Karadeniz & Trabzon \\
10. Bölge-Kuzeydoğu Anadolu & Erzurum \\
11. Bölge-Ortadoğu Anadolu & Van \\
12. Bölge-Güneydoğu Anadolu & Şanlıurfa \\
\hline
\end{tabular}




\section{Verilerin Analizi}

\section{Açımlayıcı Faktör Analizi}

Toplanan verilerin açımlayııı faktör analizi yapmaya (AFA) uygunluğunu belirlemek amacıyla küresellik testi (KMO) yapılmıştır. Yapılan KMO Bartlett's testi sonucunda KMO değeri 0.898 ve Bartlett's Ki Kare değeri ise 21209.117(p:0.000) olarak bulunmuştur. Bu değerler 108 soruluk madde havuzuna açımlayıcı faktör analizi (AFA) yapılabileceğini göstermektedir. Nitekim ilgili alan yazınında KMO değeri 0,50"den küçük ise ilgili veri grubuna faktör analizi yapılamayacağı, KMO değeri 1"e ne kadar yakın ise faktör analizinin yapılmasının o derece uygun olduğu belirtilmektedir (Akgül \& Çevik 2003; Bayram, 2009; Kalaycı, 2008).

Bir değişkenin analizde yer alan diğer değişkenlerle paylaştığı varyansın miktarına ortak varyans (communalities) denir (Hair, Anderson, Tatham \& Black, 1998). Maddelerin ortak varyansları hesaplanarak.30'un altında ortak varyans değeri alan maddelerin atılabilmesi için ortak varyans testi yapılır. Değişkenlerin ortak varyansı incelendiği zaman bütün maddelerde ortak varyans değerlerinin 1 olduğu görülmektedir. Literatür incelendiğinde ortak varyans değeri hakkında kesin bir rakam olmamakla birlikte 0.30 un altındaki değerlerin atılabileceği söylenmektedir. Bu nedenle uzman görüşü de alınarak analizde düşük ortak varyansa ( 0.30 altı) sahip olan maddelerin atılmasına karar verilmiştir. Bunu gerçekleştirmek amacıyla veriler 5 kez AFA analizine tabi tutulmuş ve beşinci uygulamanın sonunda.30'un altında ortak varyans değeri alan madde kalmamış olduğu görülmüştür. Maddenin varyansı açıklama yüzdesi (extraction) her bir maddenin toplam faktörün ne kadarını etkilediğini gösterir. Örneğin, bir maddenin varyansı açıklama yüzdesinin 30'un üzerinde olması beklenir. Genellikle, .30"un altındaki maddeler çıkarılarak işlem tekrar edilir. Bazen.10'a kadar tolere edilebilir. Sorunlu madde var ise, atılıp denenebilir ve atmaya değer mi diye kontrol edilir. Tavsiye edilen, sadece bu tabloya göre hemen madde atmamak ve ilerleyip diğer tablolarda sorun olup olmadığına bakmaktır. Ne var ki 0.10 'dan küçük değerler de çok küçüktür ve atılması düşünülebilir (Çil, 2015). Beşinci ve son kez yapılan AFA sonucunda ölçek 5 faktör ve 67 maddeden oluşmuştur. Son analizden sonra ölçeğin 5 faktörden oluştuğu Grafik 1'de, AFA açıklanan toplam varyans değerleri Tablo 2' de ve maddelerin faktörlere göre dağılımı Tablo 3' de verilmiştir.

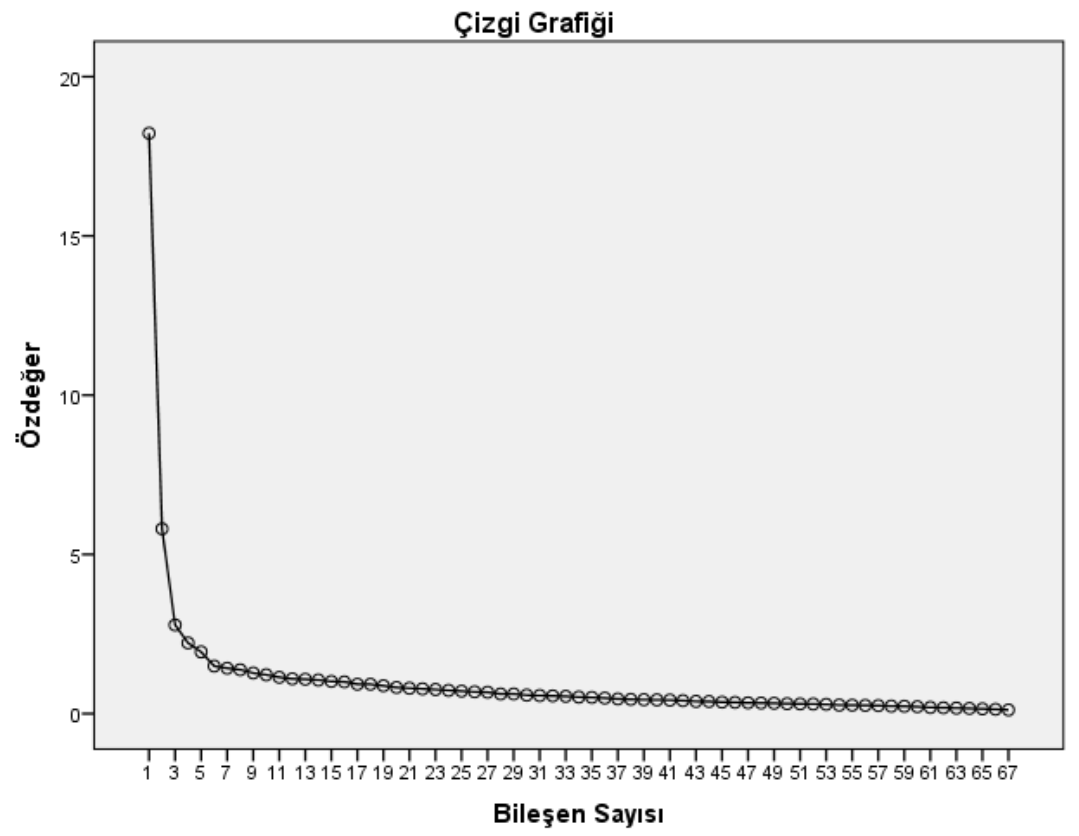

Tablo 2. AFA açıklanan toplam varyans tablosu

Grafik 1. Çizgi grafiği (scree plot)

\begin{tabular}{crrrrrr}
\hline Faktör & \multicolumn{3}{c}{ Başlangıç Öz Değerleri } & \multicolumn{3}{c}{ Döndürülmüş Faktör Yükleri } \\
\cline { 2 - 6 } & Total & $\begin{array}{c}\text { \% of } \\
\text { Variance }\end{array}$ & $\begin{array}{c}\text { Cumulative } \\
\%\end{array}$ & Total & $\begin{array}{c}\% \text { of } \\
\text { Variance }\end{array}$ & $\begin{array}{c}\text { Cumulativ } \\
\text { e } \%\end{array}$ \\
\hline 1 & 18,223 & 27,198 & 27,198 & 9,600 & 14,328 & 14,328 \\
2 & 5,803 & 8,661 & 35,859 & 9,346 & 13,949 & 28,277 \\
3 & 2,784 & 4,155 & 40,015 & 4,687 & 6,995 & 35,272 \\
4 & 2,218 & 3,311 & 43,326 & 4,035 & 6,022 & 41,293 \\
5 & 1,939 & 2,894 & 46,220 & 3,301 & 4,927 & 46,220 \\
\hline
\end{tabular}


Rotasyondan önce 1. faktörün toplam varyansı açıklama yüzdesi 18,223 , 2. faktörün toplam varyansı açıklama yüzdesi 5,803, 3. faktörün toplam varyansı açıklama yüzdesi 2,784, 4. faktörün toplam varyansı açıklama yüzdesi 2,218, 5. faktörün toplam varyansı açıklama yüzdesi 1,939 olarak bulunmuştur.

Rotasyondan sonra 1. faktörün toplam varyansı açıklama yüzdesi 14,328, 2. faktörün toplam varyansı açıklama yüzdesi $13,949,3$. faktörün toplam varyansı açıklama yüzdesi 6,995 , 4. faktörün toplam varyansı açıklama yüzdesi $6,022,5$. faktörün toplam varyansı açıklama yüzdesi ise 4,927 olarak hesaplanmıştır.

\section{Tablo 3. Maddelerin faktörlere göre dağılımı}

\begin{tabular}{|c|c|c|c|c|c|}
\hline & \multicolumn{5}{|c|}{ Faktör Bileşeni } \\
\hline & 1 & 2 & 3 & 4 & 5 \\
\hline SMEAN(s44) & 742 & & & & \\
\hline SMEAN(s99) & 741 & & & & \\
\hline SMEAN(s94) & 732 & & & & \\
\hline SMEAN(s57) & 725 & & & & \\
\hline SMEAN(s93) & 714 & & & & \\
\hline SMEAN(s49) & 688 & & & & \\
\hline SMEAN(s17) & 680 & & & & \\
\hline SMEAN(s98) & 635 & & & & \\
\hline SMEAN(s63) & 633 & & & & \\
\hline SMEAN(s45) & 597 & & & & \\
\hline SMEAN(s22) & ,589 & & & & \\
\hline SMEAN(s39) & 563 & & & & \\
\hline SMEAN(s80) & ,542 & & & & \\
\hline SMEAN(s10) & ,519 & & & & \\
\hline SMEAN(s91) & ,512 & & & & \\
\hline SMEAN(s4) & 465 & & & & \\
\hline SMEAN(s70) & 456 & & & & \\
\hline SMEAN(s77) & 444 & & & & \\
\hline SMEAN(s86) & ,422 & & & & \\
\hline SMEAN(s24) & & ,688 & & & \\
\hline SMEAN(s34) & & ,668 & & & \\
\hline SMEAN(s27) & & ,635 & & & \\
\hline SMEAN(s50) & & 606 & & & \\
\hline SMEAN(s33) & & ,580 & & & \\
\hline SMEAN(s48) & & ,580 & & & \\
\hline SMEAN(s38) & & ,578 & & & \\
\hline SMEAN(s46) & & 574 & & & \\
\hline SMEAN(s66) & & ,568 & & & \\
\hline SMEAN(s54) & & ,563 & & & \\
\hline SMEAN(s35) & & ,560 & & & \\
\hline SMEAN(s36) & & ,551 & & & \\
\hline
\end{tabular}


Faktör Bileşeni

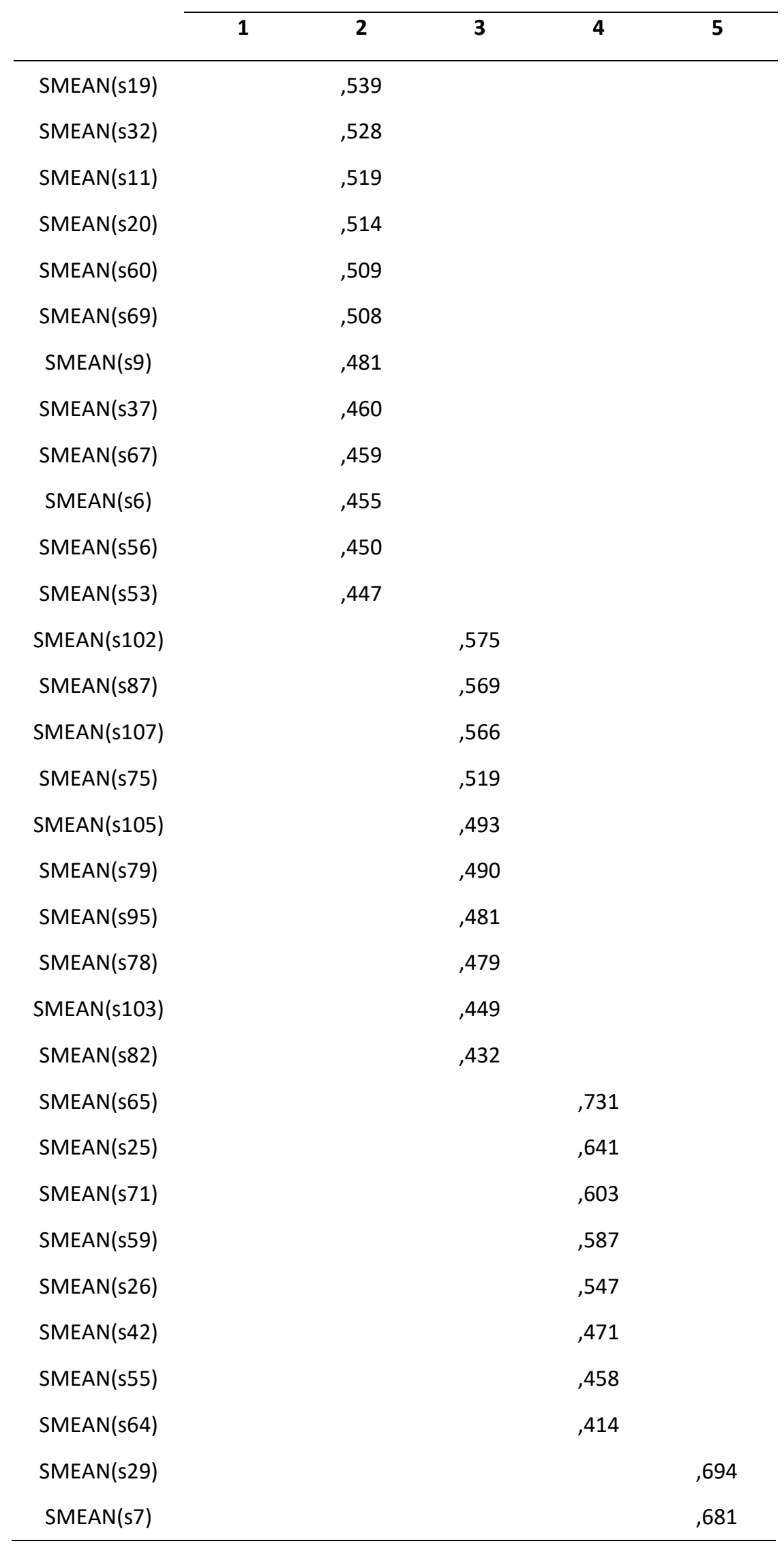




\begin{tabular}{lcccc}
\hline & \multicolumn{5}{c}{ Faktör Bileşeni } \\
\cline { 2 - 5 } & $\mathbf{1}$ & $\mathbf{2}$ & $\mathbf{3}$ & $\mathbf{4}$ \\
\hline SMEAN(s61) & & & & $\mathbf{5}$ \\
SMEAN(s40) & & & &, 560 \\
SMEAN(s74) & & &, 515 \\
SMEAN(s73) & & & &, 463 \\
\hline
\end{tabular}

\section{Güvenirlik Katsayısı}

Ölçme aracının önemli teknik özelliklerinden biri olan güvenirlik "ölçme aracının ölçtüğü özelliği ya da özellikleri ne derecede bir kararlılıkla ölçmekte olduğunun göstergesidir" (Tavşancıl, 2006; Tekin, 2006). Özdamar (1999) ise güvenirliği "bir ölçme aracında bütün soruların birbiriyle tutarlıığını, ele alınan oluşumu ölçmede türdeşliğini ortaya koyan bir kavram" olarak tanımlamıştır. Bu çerçevede ölçme aracındaki maddelerin birbirleriyle tutarılığını ve ölçmek istediği özellikleri ne derecede kararlı ölçtüğünü belirleyebilmek amacıyla güvenirlik katsayısı hesaplanmıştır.

\section{Tablo 4. Güvenilirlik Analizi}

\begin{tabular}{cccccc}
\hline \multicolumn{5}{c}{ Güvenilirlik Analizleri } \\
\hline$\overline{\mathbf{x}}$ & Varyans & Standart Sapma & Madde Sayısı & Cronbach's Alpha & Madde Sayısı \\
\hline 248,77 & 1149,594 & 33,906 & 67 & 996 & 67 \\
\hline
\end{tabular}

Tablo 4 incelendiğinde faktör analizi sonucunda kalan 67 maddenin Cronbach" Alpha katsayısı 0.946 bulunduğu görülmektedir. Bu değer 1' e ne kadar yakınsa o düzeyde güvenilirdir (Can, 2013).

\section{Friedman' Ki-Kare Testi}

Ölçek güvenilirliğini belirlemenin bir yolu da Friedman's ki-kare testidir. Maddelerin birbirleri ile ilişkilerini ortaya çıkarmak için Friedman's ki-kare testi yapılmıştır.

\section{Tablo 5. Friedman's Ki-Kare Testi}

\begin{tabular}{|c|c|c|c|c|c|c|}
\hline \multicolumn{7}{|c|}{ ANOVA (With Friedman's Test) } \\
\hline & & $\begin{array}{l}\text { Kareler } \\
\text { Toplamı }\end{array}$ & $\begin{array}{c}\text { Serbestlik } \\
\text { derecesi }\end{array}$ & $\begin{array}{l}\text { Ortalama } \\
\text { Kare }\end{array}$ & $\begin{array}{c}\text { Friedman's } \\
\text { Ki-Kare }\end{array}$ & $\mathbf{p}$ \\
\hline Gruplar arası & & 5542,073 & 323 & 17,158 & & \\
\hline \multirow[t]{3}{*}{ Grup içi } & $\begin{array}{l}\text { Maddeler } \\
\text { arası }\end{array}$ & $\begin{array}{r}10887,205 \\
a\end{array}$ & 66 & 164,958 & 7638,500 & 000 \\
\hline & Artık & 19591,554 & 21318 & ,919 & & \\
\hline & Toplam & 30478,760 & 21384 & 1,425 & & \\
\hline Toplam & & 36020,833 & 21707 & 1,659 & & \\
\hline
\end{tabular}

Ana Ortalama $=3,71$

Friedman's ki-kare testi sonucunda Friedman's ki-kare $=7638,500(p=0,000)$ bulunmuştur. Bu veriler de $(p<0,001)$ ölçme aracının güvenilir olduğunu göstermektedir (Altunışık vd., 2007).

\section{Sperman-Brown (Testi Yarılama) Testi}

Yukarıda yapılan güvenirlik testlerine ek olarak Spearman-Brown testi yarılama testi uygulanmıştır (Tablo 6). Bu testte ölçek maddeleri ikiye bölünerek her iki bölümün ayrı ayrı Cronbach's Alpha güvenilirlik katsayıları hesaplanır ve her iki bölümün arasındaki korelasyon katsayısına bakılır (Tavşancıl, 2006). 
Tablo 6. Testi Yarılama (Spearman-Brown Testi)

\begin{tabular}{|c|c|c|c|}
\hline Güvenilirlik Analizi & & & \\
\hline \multirow[t]{5}{*}{ Cronbach's Alpha } & \multirow[t]{2}{*}{ Form 1} & Değer & ,906 \\
\hline & & Madde Sayısı & $34^{\mathrm{a}}$ \\
\hline & \multirow[t]{2}{*}{ Form 2} & Değer & ,900 \\
\hline & & Madde Sayısı & $33^{b}$ \\
\hline & \multicolumn{2}{|c|}{ Toplam Madde Sayısı } & 67 \\
\hline Formalar Arası Korelasyon & & & ,832 \\
\hline \multirow[t]{2}{*}{ Spearman-Brown Coefficient } & \multicolumn{2}{|c|}{ Eşit Uzunluk } & ,908 \\
\hline & \multicolumn{2}{|c|}{ Eşit Olmayan Uzunluk } & ,908 \\
\hline
\end{tabular}

Sperman Brown testi yarılama yöntemi ile aracın güvenirliği hesaplanmış testin ilk yarı Cronbach's Alpha katsayısı 0.906 ve testin ikinci yarı Cronbach's Alpha katsayısı 0.900 ve iki soru formu (yarılanan) arasındaki korelasyon katsayısı ise 0.832 olarak bulunmuştur. Ölçeğin iç tutarlılık katsayısı (Sperman-Brown) 0,80 ile 1.00 arasında ise ölçek yüksek derecede güvenilir kabul edilmektedir (Tavşancıl, 2006). Bu bulgular ölçeğin yüksek derecede güvenilir olduğunu göstermektedir.

Faktör analizi, başlıca amacı aralarında ilişki bulunduğu düşünülen çok sayıdaki değişken arasındaki ilişkilerin anlaşılmasını ve yorumlanmasını kolaylaştırmak için daha az sayıdaki temel boyuta indirgemek veya özetlemek olan bir grup çok değişkenli analiz tekniğidir (Altunışık vd., 2007). Yapılan faktör analizi sonucunda ölçeğin 5 faktörlü olduğu bulunmuş ve ölçeğin bütün olarak güvenirlik katsayısı 0.946. olarak bulunmuştur. Bununla birlikte ölçek 5 faktörden oluştuğu için, çok sayıdaki değişken arasındaki ilişkilerin daha iyi anlaşılması açısından her bir faktör için tek tek güvenirlik analizi yapılmıştır. Bu aşamadan önce 10 okul öncesi eğitim ve 3 ölçme değerlendirme alan uzmanıyla istişare yapılarak faktörler isimlendirilmiştir. Buna göre 1. Faktör "Öğretmenlerin Öğretmen Rolleri İle İlgili Görüşleri Faktörü", 2. Faktör "Öğretmenlerin Programı ve Çocukları Değerlendirme İle İlgili Görüşleri Faktörü", 3. Faktör "Öğretmenlerin Küçük Grup Etkinliklerini Düzenleme ve Çocuğu Etkinliklerde Değerlendirme ille illgili Görüşleri Faktörü”, 4. Faktör "Öğretmenlerin Etkinlikleri Planlama İle İlgili Görüşleri Faktörü" ve 5. Faktör "Öğretmenlerin Günlük Yaşam Aktivitelerini Programa Yansıtma ve Değerlendirme İle İlgili Görüşleri Faktörü” şeklinde isimlendirilmiştir. Sonrasında her bir faktör için ayrı ayrı yapılan güvenirlik analizleri Tablo 7, 8, 9, 10 ve 11'de verilmiştir.

Tablo 7. Öğretmenlerin Öğretmen Rolleri île İlgili Görüşleri Faktörü (Faktör 1) Güvenirlik Analizi Sonuçları

\begin{tabular}{ccccc}
\hline $\mathbf{N}$ & $\begin{array}{c}\text { Güvenirlik } \\
\text { Katsayısı }\end{array}$ & $\begin{array}{c}\text { Aritmetik } \\
\text { Ortalama }\end{array}$ & Standart Sapma & Varyans \\
\hline 19 & 926 & 79,71 & 12,408 & 153,949
\end{tabular}

Öğretmenlerin öğretmen rolleri ile ilgili görüşleri faktörü 19 maddeden oluşup, 49,71 aritmetik ortalamaya, 12,408 standart sapmaya ve 153,949 varyansa sahip olup, Cronbach's Alfa güvenilirlik katsayısı 0,926 olarak bulunmuştur.

Tablo 8. Öğretmenlerin programı ve çocukları değerlendirme ile ilgili görüşleri faktörü (faktör 2) güvenilirlik analizi sonuçları

\begin{tabular}{ccccc}
\hline $\mathbf{N}$ & $\begin{array}{c}\text { Güvenirlik } \\
\text { Katsayısı }\end{array}$ & $\begin{array}{c}\text { Aritmetik } \\
\text { Ortalama }\end{array}$ & Standart Sapma & Varyans \\
\hline 24 &, 929 & 96,82 & 14,849 & 220,487 \\
\hline
\end{tabular}

Öğretmenlerin programı ve çocukları değerlendirme ile ilgili görüşleri faktörü 24 maddeden oluşup, 96,82 aritmetik ortalamaya, 14,849 standart sapmaya ve 220,487 varyansa sahip olup, Cronbach's Alfa güvenilirlik katsayısı 0,929 'dur. 
Tablo 9. Öğretmenlerin küçük grup etkinliklerini düzenleme ve çocuğu etkinliklerde değerlendirme ile ilgili görüşleri faktörü (faktör 3) güvenilirlik analizi sonuçları

\begin{tabular}{ccccc}
\hline $\mathbf{N}$ & $\begin{array}{c}\text { Güvenirlik } \\
\text { Katsayısı }\end{array}$ & $\begin{array}{c}\text { Aritmetik } \\
\text { Ortalama }\end{array}$ & Standart Sapma & Varyans \\
\hline 10 &, 814 & 35,08 & 6,920 & 47,886 \\
\hline
\end{tabular}

Öğretmenlerin küçük grup etkinliklerini düzenleme ve çocuğu etkinliklerde değerlendirme ile ilgili görüşleri faktörü 10 maddeden oluşup, 35,08 aritmetik ortalamaya, 6,920 standart sapmaya ve 47,886 varyansa sahiptir. Cronbach's Alfa güvenilirlik katsayısı ise 0,814 olarak bulunmuştur.

Tablo 10. Öğretmenlerin etkinlikleri planlama ile ilgili görüşleri faktörü (faktör 4) güvenirlik analizi sonuçları

\begin{tabular}{ccccc}
\hline $\mathbf{N}$ & Güvenirlik Katsayısı & Aritmetik Ortalama & Standart Sapma & Varyans \\
\hline 8 & 1764 & 19,25 & 6,103 & 37,250 \\
\hline
\end{tabular}

Öğretmenlerin etkinlikleri planlama ile ilgili görüşleri faktörü 8 maddeden oluşup, 19,25 aritmetik ortalamaya, 6,103 standart sapmaya ve 37,250 varyansa sahiptir. Cronbach's Alfa güvenirlik katsayısı ise 0,764'tür.

Tablo 11. Öğretmenlerin günlük yaşam aktivitelerini programa yansıtma ve değerlendirme ile ilgili görüşleri faktörü (faktör 5) güvenirlik analizi sonuçları

\begin{tabular}{ccccc}
\hline $\mathbf{N}$ & Güvenirlik Katsayısı & Aritmetik Ortalama & Standart Sapma & Varyans \\
\hline 6 &, 762 & 17,91 & 5,134 & 26,362 \\
\hline
\end{tabular}

Öğretmenlerin günlük yaşam aktivitelerini programa yansıtma ve değerlendirme ile ilgili görüşleri faktörü 6 maddeden oluşup, 17,91 aritmetik ortalamaya, 5,134 standart sapmaya ve 26,362 varyansa sahiptir. Cronbach Alfa güvenilirlik katsayısı ise 0,762 olarak hesaplanmıştır.

\section{Doğrulayıcı Faktör Analizi}

Açımlayıcı faktör analizi sonuçları doğrultusunda 5 faktör ve 67 maddeden oluşan ölçek Adana, Ankara, Bursa, Eskişehir, İstanbul, İzmir, Kastamonu ve Van illerinde resmi ve özel okulöncesi eğitim okullarında görev yapan ve lisans mezunu 978 öğretmene ulaşılmış ve uygulanmıştır. Katılımcıların illere göre dağılımı Tablo 12'de verilmiştir. Katılımcılardan dönen formlar incelenmiş, hatalı doldurulanlar ve üç sorudan daha fazla maddeyi boş bırakanlar çıkarıldıktan sonra toplam 877 öğretmene ait verinin doğrulayıcı faktör analizine (DFA) tabi tutulması kararlaştırılmıştır. DFA için IBM AMOS 22 programı kullanılmıştır.

Tablo 12. illere göre veri sayıları

\begin{tabular}{cccc}
\hline iller & Ulaşılan veri sayısı & $\begin{array}{c}\text { Analize dâhil edilmeyen veri } \\
\text { sayısı }\end{array}$ & $\begin{array}{c}\text { Analizde kullanılan veri } \\
\text { sayısı }\end{array}$ \\
\hline Adana & 94 & 5 & 89 \\
Ankara & 151 & 12 & 139 \\
Bursa & 84 & 15 & 69 \\
Eskişehir & 79 & 8 & 71 \\
İstanbul & 279 & 41 & 238 \\
İzmir & 147 & 13 & 134 \\
Kastamonu & 61 & 1 & 60 \\
Van & 83 & 6 & 77 \\
\hline Toplam & 978 & 101 & 877 \\
\hline
\end{tabular}

\section{Birinci Uygulama}

Yapılan ilk DFA uygulamasında dağılımın normalliğini bozan 11 madde çıkarılmış ve tekrar DFA yapılmıştır. Birinci uygulamanın DFA sonuçları Tablo 14'de verilmiştir. 


\section{İkinci Uygulama}

Yapılan ikinci DFA sonrasında modifikasyon değerleri incelendiğinde 23 maddenin birbirleriyle modifiye edilmesi gerektiği ortaya çıkmıştır. Modifiye edilmesi gereken maddelerin çokluğundan dolayı ikinci bir yöntem olan maddelerin silinmesi yoluna gidilmiş̧ir. AMOS programı modelin iyi uyum sağlaması için bağlantı kurmak veya bağlantıyı silmek ve değişkenler arasında hata varyansı eklemek veya çıkartmak olmak üzere iki çeşit modifikasyon indeksi önermektedir (Koçak, Yılmaz ve Gökler, 2013). İkinci uygulamanın DFA sonuçları Tablo 14'de verilmiştir.

\section{Üçüncü Uygulama}

Yapılan üçüncü DFA sonucunda normallik testi kurtosis değerleri 1,66 ile 1,33 arasında, skewness değerlerinin ise 1,66 ile 1,43 arasında değiştiği bulunmuştur. 23-29, 22-28 ve 26-29. maddeler arasında modifikasyon yapılmıştır. Modifikasyon değerleri Tablo 13'de, üçüncü uygulamanın DFA sonuçları Tablo 14'de verilmiştir.

Tablo 13. Modifikasyon değerleri

\begin{tabular}{cccc}
\hline \multicolumn{2}{c}{ Madde } & \multicolumn{2}{c}{ Değişim $\%$} \\
\hline e23 & $<-->$ e29 & 21,49 &,- 20 \\
e22 & $<-->$ e28 & 13,72 &, 12 \\
e26 & $<-->$ e29 & 4,78 &, 11 \\
\hline
\end{tabular}

Yapılan DFA sonucunda ortaya çıkan modifikasyon indeksleri incelendiğinde 23 ile 29. madde, 22 ile 28. madde ve 26 ile 29. maddelerin birlikte ele alınması ve modelin değiştirilmesi gerektiği görülmüştür (Tablo 12). Modifikasyon öncelikle $\chi^{2}$ değerinde en fazla değişimi sağlayan maddelerden başlanarak aşama aşama yapılmış Tablo 13 'de belirtilen üç modifikasyondan sonra uyum iyiliği değerlerinin daha da iyileştiği görülmüştür (Tablo 14).

\section{Dördüncü Uygulama}

Dördüncü ve son DFA uygulamasında 5 faktör ve 33 soru maddesi analize tabi tutulmuştur. Analiz sonucunda ulaşılan değerler Tablo 14'de ve Şekil 1'de verilmiştir.

\section{Tablo 14. Uyum iyiliği değerleri}

\begin{tabular}{lcccccccccccc}
\hline Model & $\mathbf{N}$ & Madde Sayıs & $\boldsymbol{u}^{2}$ & $\mathbf{d f}$ & $\mathbf{p}$ & $\boldsymbol{u}^{2} / \mathbf{d f}$ & GFI & CFI & AGFI & RMSEA & RMR & SRMR \\
\hline 1 & 877 & 67 & 7318,7 & 2134 & 0,00 & 3,43 & 0,77 & 0,70 & 0,76 & 0,05 & 0,08 & 0,07 \\
2 & 877 & 56 & 5358,2 & 1474 & 0,00 & 3,63 & 0,80 & 0,70 & 0,78 & 0,05 & 0,08 & 0,07 \\
3 & 877 & 33 & 1332,4 & 485 & 0,00 & 2,74 & 0,914 & 0,86 & 0,90 & 0,05 & 0,06 & 0,05 \\
4 & 877 & 33 & 1290,8 & 482 & 0,00 & 2,67 & 0,917 & 0,87 & 0,90 & 0,04 & 0,06 & 0,05
\end{tabular}

Alanyazına dayalı olarak modelin uyum değerlerinin kabul edilebilir sınırlar içerisinde olduğu; Tablo 14'de Model 4'deki DFA' nın uyum iyiliği değerleri incelendiğinde değerlerin kabul edilebilirliği görülmektedir. $\varkappa^{2} / \mathrm{df}$ değerinin 5 in altında olması, GFI nin 0,90'dan büyük olması, RMSEA ve RMR değerlerinin 0,08'in altında olması kabul edilebilir bir uyum iyiliğini ifade etmektedir.

Yenel'in (2016:90) ve Daşçı'nın (2014:62) Sümer (2000:61)'den aktardığına göre RMSA değerinin ,05'in altında olmasının mükemmel uyumun göstergesi olduğu ifade edilmektedir. Hu ve Bentler (1999:26) ise ,05'in altındaki değerin iyi uyumun bir göstergesi olduğunu ifade etmektedir. Steiger (1990), Browne ve Mels (1990), Browne ve Cudeck (1992) RMSEA değerinin ,05'in altında olmasının modelin uyumlu olduğunun göstergesi olduğunu ifade etmişlerdir. Ayrıca Browne and Cudeck (1992) RMSA değerinin ,05-,08 arasında olmasının kabul edilebilir uyumu gösterdiğini, ,10'un üzeri değerin ise zayıf uyumu gösterdiğini ifade etmişlerdir.

$\chi 2 / s d$ değerinin beşten ya da bazı kaynaklara göre ise üçten düşük olması, iyi uyumun göstergesi olarak görülmektedir (Şimşek, 2007, Tabachnick ve Fidell, 2013). Büyük örneklemlerde, $\chi 2 / s d$ yeterlik için bir ölçüt olarak kullanılabilir (Çokluk, Şekercioğlu, Büyüköztürk, 2012). Ancak, x2/sd değerine ek olarak, diğer uyum indekslerinin de dikkate alınmasında fayda görülmektedir (Çelik ve Yılmaz, 2013). Yapılan modifiye ve analizler sonucunda uyum iyiliği değerlerinin de alanyazında görülebileceği gibi kabul edilebilir düzeyde olduğu bulunmuştur(Tablo 14). 


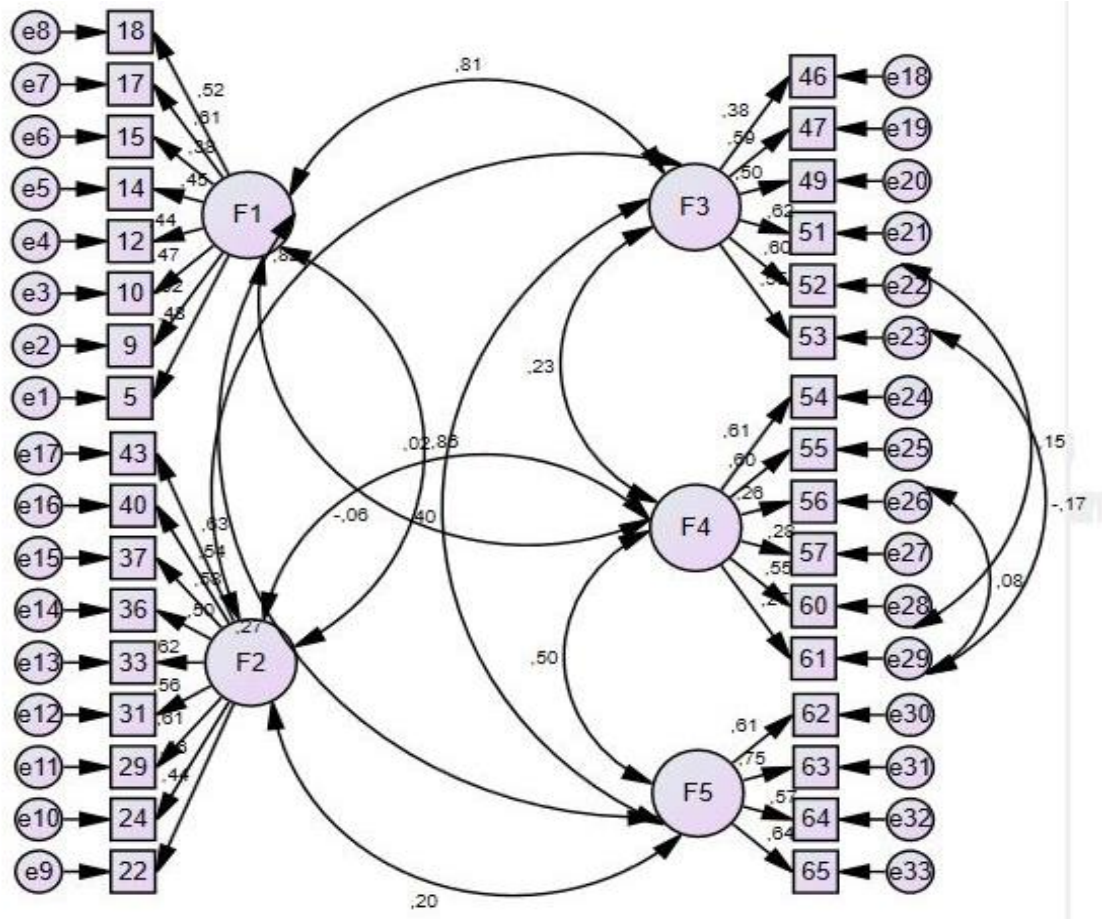

Şekil 1. DFA yol diyagramı

\section{Sonuç ve Tartışma}

Ölçeğin geçerlik çalışmaları kapsamında alanyazın taraması ve uzman görüşü alınarak çalışmalar yürütülmüştür ve uzman görüşleri doğrultusunda ölçek oluşturulmuştur. Ölçeğin güvenirlik çalışmaları için elde edilen verilere sırasıyla verilerin açımlayıcı faktör analizi yapmaya uygunluğunu belirlemek için küresellik testi, ölçeğin kaç faktörden oluştuğunu belirlemek için çizgi grafiği analizi, ölçek maddelerinin varyansı açıklama değerlerini belirlemek için açımlayıcı faktör analizi, ölçme aracındaki maddelerin birbirleriyle tutarlılığını ve ölçmek istediği özellikleri ne derecede kararlı ölçtüğünü belirleyebilmek için güvenilirlik katsayısı hesaplama analizi, ölçekteki her bir maddenin bütün ölçekteki korelasyon katsayısının hesaplanması için madde analizi uygulanmıştır. Ayrıca ölçme aracının güvenilir olduğunu belirlemenin bir başka yolu olan Friedman"s Ki-Kare testi ve Sperman-Brown (Testi Yarılama) Testi uygulanmıştır.

Yapılan KMO Bartlett testi sonucunda KMO değeri 0.898 ve Bartlett Ki Kare değeri ise 21209.117(p:0.000) olarak bulunmuştur. Yapılan AFA sonucunda çizgi grafiğinde veri toplama aracının 5 faktörlü olduğu saptanmıştır. Ölçekteki 1. faktörün toplam varyansı açıklama yüzdesi 14,328 , 2. faktörün toplam varyansı açıklama yüzdesi 13,949, 3. faktörün toplam varyansı açıklama yüzdesi 6,995 , 4 . faktörün toplam varyansı açıklama yüzdesi 6,022 , 5. faktörün toplam varyansı açıklama yüzdesi ise 4,927 olarak hesaplanmıştır.

Faktör analizi sonucunda ölçekte kalan 67 maddenin Cronbach" Alpha katsayısı 0.946 bulunmuştur. Friedman's ki-kare testi sonucunda Friedman's ki-kare $=7638,500(p=0,000)$ bulunmuştur. Sperman Brown testi yarılama yöntemi ile aracın güvenirliği hesaplanmış testin ilk yarı Cronbach's Alpha katsayısı 0.906 ve testin ikinci yarı Cronbach's Alpha katsayısı 0.900 ve iki soru formu (yarılanan) arasındaki korelasyon katsayısı ise 0.832 olarak bulunmuştur. Ölçek 5 faktörden oluştuğu için, çok sayıdaki değişken arasındaki ilişkilerin daha iyi anlaşılması açısından her bir faktör için tek tek güvenirlik analizi yapılmıştır. Bu doğrultuda, öğretmenlerin öğretmen rolleri ile ilgili görüşleri faktörü 19 maddeden oluşup, 49,71 aritmetik ortalamaya, 12,408 standart sapmaya ve 153,949 varyansa sahip olup, Cronbach's Alfa güvenilirlik katsayısı 0,926 olarak bulunmuştur. Öğretmenlerin programı ve çocukları değerlendirme ile ilgili görüşleri faktörü 24 maddeden oluşup, 96,82 aritmetik ortalamaya, 14,849 standart sapmaya ve 220,487 varyansa sahip olup, Cronbach"s Alfa güvenilirlik katsayısı 0,929 olarak saptanmıştır. Öğretmenlerin küçük grup etkinliklerini düzenleme ve çocuğu etkinliklerde değerlendirme ile ilgili görüşleri faktörü 10 maddeden oluşup, 35,08 aritmetik ortalamaya, 6,920 standart sapmaya ve 47,886 varyansa sahiptir. Cronbach's Alfa güvenilirlik katsayısı ise 0,814 olarak bulunmuştur. Öğretmenlerin etkinlikleri planlama ile ilgili görüşleri faktörü 8 maddeden oluşup, 19,25 aritmetik ortalamaya, 6,103 standart sapmaya ve 37,250 varyansa sahiptir. Cronbach's Alfa güvenirlik katsayısının ise 0,764 olduğu sonucuna 
ulaşılmıştır. Öğretmenlerin günlük yaşam aktivitelerini programa yansıtma ve değerlendirme ile ilgili görüşleri faktörü 6 maddeden oluşup, 17,91 aritmetik ortalamaya, 5,134 standart sapmaya ve 26,362 varyansa sahiptir. Cronbach's Alfa güvenilirlik katsayısı ise 0,762 olarak bulunmuştur.

Açımlayıcı faktör analizi sonuçları doğrultusunda 67 madde ve beş faktörden oluşan ölçek, dört kez DFA uygulamasına tabi tutulduğunda 34 madde ölçekten çıkarılmış, faktör sayısı ise aynı kalmıştır. DFA uygulamaları sonucunda çıkarılan soru maddelerinin çoklu zekâ ve gelişimsel etkileşim yaklaşımları ile ilgili olduğu görülmüştür. Çoklu zekâ yaklaşımının öne sürdüğü zekâ anlayışında anahtar sözcük "çoğul"dur ve zekâ çok yönlü bir bütündür (Saban, 2002). Gelişimsel etkileşim yaklaşımında da "bütünüyle çocuk" anlayışından kaynaklanan bütüncül gelişime dayalı eğitim söz konusudur (Anonim, 2019; Bayhan \& Bencik, 2008). Bu sebeplerle DFA'da iki yaklaşımın benzer uygulamalarını içeren maddelerin analiz dışı bırakıldığı görülmüştür. Bu durum da her iki yaklaşımın birbirinden farklı olsa bile bütüncül gelişim anlayışını benimsemelerinden kaynaklanıyor olabilir. Yapılan tüm bu çalışmalardan sonra 33 madde ve 5 faktörden oluşan "okulöncesi eğitim programını değerlendirme ölçeği" (OEPDÖ) alanyazına ve uygulayıcılara kazandırılmıştır.

\section{4. Öneriler}

Bu çalışma, MEB Okul Öncesi Eğitim Programını değerlendirme ölçeği hazırlamak amacıyla yapılmıştır. Ölçek MEB Okul Öncesi Eğitim Programını; Davranışçı (direk komut), Çoklu zekâ, Waldorf, Montessori (Duyuşsal biliş̧), Bank Street (Gelişimsel etkileşim) ve High Scope (Bilişsel gelişimcilik) yaklaşımlarının benimsediği uygulamalar temel alınarak eklektik bir anlayışla geliştirilmiştir. Bundan sonraki ölçek geliştirme çalışmalarında, bu çalışmada yer almayan Reggio Emilia, Head Start ve Açık Okul gibi programların da eklektik yapıya dahil edilmesi araştırmacılara önerilebilir.

Geliştirilen bu ölçek, okulöncesi program geliştirme komisyonlarının yeni program tasarlama çalışmalarında, destekleyici bir veri toplama aracı olarak kullanılabilir.

\section{Kaynakça}

Akgül, A. \& Çevik, O. (2003). İstatistiksel analiz teknikleri SPSS'de işletme yönetimi uygulamaları. Ankara: Emek Ofset.

Akınoğlu, O. (2005). Türkiye'de uygulanan ve değişen eğitim programlarının psikolojik temelleri. M. Ü. Atatürk Eğitim Fakültesi Eğitim Bilimleri Dergisi. (22), 31-46.

Altunışık, R., Coşkun R., Bayraktaroğlu S. \& Yıldırım E. (2007). Sosyal bilimlerde araştırma yöntemleri (SPSS uygulamalı). Sakarya: Sakarya Yayıncılık.

Armstrong, T. (2009). Multiple intelligences in the classroom. USA: ASCD.

Anonim. (2019). Bank street yaklaşımı. 16.04.2019 tarihinde https://www.acevokuloncesi.org/egitim-programi/farkliprogram-ve-yaklasimlar/bank-street-yaklasimi adresinden erişildi.

Arslan, M. (2007). Eğitimde yapılandırmacı yaklaşımlar. Ankara Üniversitesi. Eğitim Bilimleri Fakültesi Dergisi. 40 (2) 1. 41-61

Azar, A, Presley, A.I, \& Balkaya, Ö. (2006). Çoklu zekâ kuramına dayalı öğretimin öğrencilerin başarı, tutum, hatırlama ve bilişsel süreç becerilerine etkisi. H.Ü. Eğitim Fakültesi Dergisi 30, 45-54.

Bayhan, P. \& Bencik, S., (2008). Erken çocukluk dönemi programlarından Waldorf yaklaşımına genel bir bakış. Selçuk Üniversitesi Ahmet Keleşoğlu Eğitim Fakültesi Dergisi, 26, 15- 25.

Bayhan, P. \& Bencik, S. (2008). Bank Street yaklaşımının (gelişimsel etkileşim yaklaşımı) ilkeler, program ve eğitimci açısından incelenmesi. Eğitim ve Bilim. 33(4), 80-88.

Bayram, N. (2009). Sosyal bilimlerde SPSS ile veri analizi, Bursa: Ezgi.

Bilasa, P. (2006). NLP (Neuro linguistic programming) (Beyin dili programlaması) pratisyenlik eğitim programının değerlendirilmesi (Yüksek Lisan Tezi). .Ankara Üniversitesi Eğitim Bilimleri Enstitüsü, Ankara.

Browne, M. and G. Mels, 1990. Ramona user's guide, columbus: Department of psychology, Ohio State University.

Browne, M. W., and R. Cudeck, 1992, "Alternative ways of assessing model fit". Sociological methods\&Research, 21(2), 230-259.

Brualdi, A. (1998). Gardner's theory. Teacher Librarian. 
Büyüköztürk, Ş., Akgün, E. A, Karadeniz, Ş., Demirel, F. \& Kılıç, E. (2008). Bilimsel araştırma yöntemleri. Ankara: PegemA yayıncilık.

Büyüköztürk, Ş. (2005) Anket geliştirme. http://www.tebd.gazi.edu.tr/arsiv/2005_cilt3/sayi_2/133-151.pdf .

Çelik, H. E., ve V. YıImaz, 2013. LISREL 9.1 ile yapısal eşitlik modellemesi: Temel kavramlar, uygulamalar, programlama, Ankara: Anı.

Çil, A. (2015). Faktör analizi (ileri istatistik notları). 20 Kasım 2015 tarihinde erişilmiştir. http://abdulrezzakcil.blogspot.com.tr/2014/05/faktor-analizi-ileri-istatistik.html

Çokluk, Ö., Şekercioğlu, G. ve Büyüköztürk, Ş, (2012). Sosyal bilimler için çok değişkenli istatistik, SPSS ve LISREL uygulamaları, Ankara: Pegem.

Daoust, C. J. (2004). An examination of implementation practices in Montessori early childhood education (Unpublished Dissertation Thesis). University of California, Berkeley.

Daşçı, E. 2014. Iköğretim Kurumu Yöneticilerinin Liderlik Tarzları ile Öğretmenlerin Yaşadıkları Yıldırma (Mobbing) ve Örgütsel Sessizlik Davranışları Arasındaki ilişki. Yayınlanmamış Yüksek Lisans Tezi Gazi Üniversitesi Eğitim Bilimleri Enstitüsü)

Demirel, Ö. (2003). Kuramdan uygulamaya eğitimde program geliştirme. Ankara: PegemA Yayıncılık.

Goodnough, K. (2001). Multiple intelligences theory: A framework for personalizing science curricula. School Science and Mathematics, 101(4), 180-193.

Gordon, M. \& Browne, K. W. (2014). Beginning essantials in early childhood education. Cengage Learning. Boston. USA.

Hair, J.F., Anderson, R. E., Tatham, R. L. \& Black W. C. (1998). Multivariate data analysis. New Jersey: Prentice Hall.

Hu, L., \& Bentler, P. M. (1999). Cut off criteria for fit indexes in covariance structure analysis: Conventional criteria versus new alternatives. Structural Equation Modeling: A Multidisciplinary Journal, 6(1), 1-55. DOI: $10.1080 / 10705519909540118$

Jensen, K. M. (2004). Development of the early childhood curricular beliefs, inventory: an instrument to identify preservice, teachers' early childhood curricular orientatıon. The Florıda State Unıversıty College Of Educatıon

Kalaycı, Ş. (2008). SPSS uygulamalı çok değişkenli istatistik teknikleri. Ankara: Asil.

Kalıpçı, S. (2008) Okul öncesi öğretmenlerin uygulamalarında benimsedikleri eğitimsel yaklaşımları belirleme (Yüksek Lisan Tezi). Marmara Üniversitesi. Eğitim Bilimleri Enstitüsü. İstanbul.

Kartal, H. (2008). Geçmişten Günümüze Erken Çocukluk Eğitimi Uygulamaları. (1. Baskı). Bursa: Ezgi Kitabevi Yayınları

Kaya, D., Gündüz, M. (2015). Alternatif eğitim ve toplumsal değişim üzerindeki etkisi: “Waldorf okulları örneği”. Milli Eğitim. Sayı 205. Kış/2015. 5-25.

Koçak, R,Yılmaz, D ve Gökler, R (2013). Okul yöneticilerinin yetki kullanımı kaygı ölçeği

(OYKÖ):geçerlik ve güvenirlik çalışması, International Journal of Social Science, 6 (8), 395-415.

Lynn, Shiplay Gay \& Obain, C. Stephan. (1996). A review of for preschool programs: A preschool model that works. Annual Meeting of the Midd-Western Educational Research Association, October 2-5, Chicago, IL.

Milli Eğitim Bakanlığı Temel Eğitim Genel Müdürlüğü (2013). Okul öncesi eğitim programı. Ankara.

Montessori, M. (1997). Çocuk Eğitimi, Montessori Metodu. Güler Yücel (Çev.). (5. Baskı), İstanbul: Özgür Yayınları.

Oktay, A. (2004). Yaşamın sihirli yılları: Okul öncesi dönem. İstanbul: Epsilon.

Özbay, Y. (2004). Gelişim ve öğrenme psikolojisi kuram-araştırma ve uygulama. Ankara: Öğreti.

Özdamar, K. (1999). Paket Programları ile Istatistiksel Veri Analizi-1, 2. Baskı, Kaan Kitapevi, Eskişehir.

Özden, Y. \& Şimşek H. (1998). Davranış̧ılıktan oluşturmacılığa: “öğrenme” paradigmasının dönüşümü ve Türk eğitimi. Bilgi ve Toplum Dergisi. 1, 1-18.

Saban, A. (2002). Öğrenme öğretme süreci yeni teori ve yaklaşımlar. Ankara: Nobel. 
Schweinhart, L. (2002). The High Scope preschool curriculum: What is it? Why use it? National Dropout Preventation Center and Network. 8, 13-16.

Senemoğlu, N. (2005). Gelişim öğrenme ve öğretim kuramdan uygulamaya. Ankara: Gazi.

Soydan, S. (2013). Erken çocukluk yaklaşımlarına ilişkin görüşler ölçeği "nin Türkçe uyarlaması: Geçerlik ve güvenilirlik çalışması. Kırşehir Eğitim Fakültesi Dergisi, 14(1), 227-247.

Steiger, J. H. (1990): Structural Model Evaluation and Modification: An Interval Estimation Approach. ultivariate behavioral Research 25(2) 173-180

Sönmez, V. (1998). Sosyal bilgiler öğretimi. Ankara: Anı Yayıncılık.

Sümer, N. (2000). Yapısal eşitlik modelleri: Temel kavramlar ve örnek uygulamalar. Türk Psikoloji Yazıları, 3(6), 49-74.

Şafak, P. (2011). Davranışçı öğrenme kuramı. F. Büyükalan (Ed.), Öğrenme öğretme kuram ve yaklaşımları içinde (s. 2745). Ankara: Pegem Akademi

Şener, E., (2001). Okul öncesi eğitim merkezleri için değişebilir/ dönüşebilir/ esnek bir 'fiziksel çevre modeli' (Doktora Tezi). İ.T.Ü. Fen Bilimleri Enstitüsü, İstanbul.

Şimşek, Ö. F. (2007). Yapısal eşitlik modellemesine giriş, temel ilkeler ve LISREL uygulamaları. Ankara: Ekinoks.

Tabachnick, B. G. ve Fidell, L. S. (2013). Using Multivariate Statistics. (Sixth edition), Pearson: NewYork

Taş, B. (2006) AB Uyum Sürecinde Türkiye İçin Yeni Bir Bölge Kavramı: İstatistiki Bölge Birimleri Sınıflandırması (IBBS), Afyon Kocatepe Üniversitesi Sosyal Bilimler Dergisi, 8 (2), 185-197.

Tavşancıl, E. (2006). Tutumların ölçülmesi ve SPSS ile veri analizi. Ankara: Nobel Yayın Dağıtım.

Tekin, H. (2006). Eğitimde ölçme ve değerlendirme. Ankara: Yargı Yayınları.

Temel, Z. F. (1994). Montessori"nin görüşleri ve eğitim yaklaşımı. Okul-Öncesi Eğitim Dergisi. 26 (47), 18-22.

Tertemiz, N. (1997). Eğitimde Program Geliştirme. L. Küçükahmet (Ed.), Eğitim bilimine giriş içinde (s. 185-203). Ankara: Gazi Kitabevi

Toran, M. (2011). Montessori yönteminin çocukların kavram edinimi, sosyal uyumları ve küçük kas motor becerileri üzerindeki etkisinin incelenmesi (Doktora tezi). Gazi Üniversitesi Eğitim Bilimleri Enstitüsü. Ankara.

Toran, M. (2014). Steiner pedagojisi ve waldorf okulları. Z. Fulya Temel (Ed.) Her yönüyle okul öncesi eğitim içinde (s.1841). Ankara, Hedef Basın Yayın.

Toran, M. \& Temel, Z. F. (2014). Montessori yaklaşımının çocukların kavram edinimi üzerindeki etkisinin incelenmesi. ilköğretim Online 13 (1). 223-234.

Tuğrul, B. \& Duran, E. (2003). Her çocuk başarılı olmak için bir şansa sahiptir: zekânın çok boyutluluğu çoklu zeka kuramı. Hacettepe Üniversitesi Eğitim Fakültesi Dergisi 24, 224-233.

Tuncer, B. (2015). Okul öncesi eğitimindeki çağdaş yaklaşımların incelenmesi ve meb okul öncesi eğitim programı ile karşılaştırılması. International Journal of Field Education, 1(2), 39-58.

Ünver, N. (2016). Okulöncesi eğitim programını değerlendirme ölçeğinin geliştirilmesi ve bu ölçeğe bağlı olarak öğretmenlerin uygulamalarını değerlendirmeleri (Doktora tezi). Gazi Üniversitesi Eğitim Bilimleri Enstitüsü. Ankara.

Varış, F. (1994). Eğitimde program geliştirme, teori ve teknikler. Ankara: Alkım.

Weikart, P. D. (1971). Relationship of Curriculum, Teaching, and Learning in Preschool Education. http://files.eric.ed.gov/fulltext/ED049837.pdf 25.05.2016.

Williams, Margaret. (1996). Plato, Piaget, and Montessori: A study of development theories (Unpublished Dissertation Thesis). Baylor University, Texas.

Woods, P., Ashley, M., \& Woods, G. (2005). Steiner Schools in England. Department for Education and Skills, London.

Yenel, K. (2016). İlkokul yöneticilerinin dönüşümcü ve işlemci liderlik biçimleri ile öğretmenlerin örgütsel vatandaşlık ve örgütsel sessizlik davranışları arasındaki ilişki. Yayınlanmamış Yüksek Lisans Tezi Gazi Üniversitesi Eğitim Bilimleri Enstitüsü) 
Yıldız, F. Ü. (2000). Deneysel yaratıcılık programının 4-5 yaş çocuklarının sosyal ve bilişsel gelişimlerine etkileri (Yüksek lisans tezi). Selçuk Üniversitesi Sosyal Bilimler Enstitüsü, Konya. 